\title{
University Students' Metacognitive Awareness in Listening to English as a Foreign Language
}

\author{
Wiwiet Eva Savitri \\ Universitas Negeri Surabaya \\ Surabaya, Indonesia \\ wiwieteva@unesa.ac.id
}

\author{
Syafi'ul Anam \\ Universitas Negeri Surabaya \\ Surabaya, Indonesia \\ syafiul.anam@unesa.ac.id
}

\begin{abstract}
Grabbing meanings in oral texts is not always easy. Therefore, listening is considered as a difficult task by many learners of English as a foreign language. The preliminary study of this research even revealed that students of English Department still face this problem. To ease the task, it is essential for students to know and apply suitable listening strategies as well as to have awareness related to their learning. Yet, whether or not students have the awareness and know the strategies are still questioned. Hence, a research was conducted and this article attempts to share the findings of an investigation on the metacognitive awareness of sophomore students regarding their listening comprehension in English and the strategies they use to understand listening texts. Sophomore students of English education department were chosen because they met the criteria to be the participants of this study i.e. they had joined some level of listening courses in the department. They are considered have adequate experiences in listening class. The data in this study was obtained through questionnaires (MALQ, Vandergrift et al, 2006). Results showed that the students were fairly aware of all aspects of metacognitive strategies and knowledge. Unlike those who were only tested, students who perceived of being trained in using listening strategies had higher metacognitive awareness.
\end{abstract}

Keywords-metacognitive awareness, strategies, listening

\section{INTRODUCTION}

Effective listening is a significant predictor of students' achievement [20]. However, Mendelsohn [12] contended that students' listening skills are not good enough to allow them to understand information in lectures. Even the teaching of listening in teacher-training based university which does not guarantee the students success in listening nor mastering listening strategies. Goh [4] admits that she herself felt that her way of teaching listening had been an example of testing rather than teaching listening. She then made an effort to apply a different listening teaching procedure. She replicated Vandergrift's [20] procedure which involves the activation of student's cognition. The result showed that pair and group discussions in listening class had helped students to enhance their understanding the material they listened. Moreover, the students also learnt more strategies. Yet, there are still many teachers who are not aware of it. Hence, there are still many listening classes in which students are not taught but merely tested. Merely being tested hinders the students to know listening strategies. Consequently, they also do not recognize their own metacognitive strategies, and are not aware with their own metacognition. Or in other words, it can be said that the students have no metacognitive awareness towards their learning of listening.

There have been many studies on the correlation between metacognitive strategies and a language learning skill, especially in Indonesian context. Yet, there are only few studies on students' metacognitive awareness and its contribution to the success of learning. Based on the discussion above, it can be concluded that more studies on metacognitive awareness especially in learning listening need conducting. Since English in Indonesia is a foreign language for most people, this paper will focus its discussion on students' metacognitive awareness in listening to English as a foreign language. The participants of this study are sophomore students in university who have taken 3 different levels of listening classes in three different semesters. They are taken as participants because they are considered 'experienced' in listening classes.

\section{LITERATURE REVIEW}

\section{A. Listening comprehension and strategies}

Listening comprehension, according to Rost [16], is the process of structure building in which the listener relates language to previously stored knowledge in his/her brain with the aim of seeking coherence and relevance. Therefore, comprehension refers to the experience of understanding whether the aural input refers to the listener's experience or to the outside world, while perceiving any chunks of language that might support or alter the information heard. Vandergrift [20], Goh [4], and Hinkel [6] recommend combining and using multiple strategies to yield best practices for listening. In line with it, Vandergrift [20] proposes five lessons representing different stages of listening which are applied with different listening strategies for each stage. Yet, students are not automatically aware of the strategies. They need guidance related to listening strategies from their teacher during the class and need to be introduced the way of how to recognize the strategies. To help them understand the strategies, the teaching of listening should help students as the learners develop metacognitive knowledge and strategies because they need to learn effective ways of listening [2] [3] [4] [8].

According to Segalowitz [17], listeners develop from controlled to automatised processing of spoken information while they build increasingly sophisticated neural networks for faster parallel processing of text and meaning. In line with it, Tyagi [19] states that listening strategies are techniques or 
process which help learners comprehend listening inputs. The strategies are applied to listening process consisting of five stages, i.e. hearing, understanding, remembering, evaluating, and responding. Thus, listening is an active process in that learners listen, combine what they hear with other information that is already familiar to get the meaning by combining what is heard with their existing knowledge [5] [16] [18].

Related to the process of teaching listening, listening instruction should involve training learners explicitly in how to listen effectively and can be an opportunity for them to develop greater awareness about strategies for comprehension [7] [13]. This type of process-based listening instruction is referred as metacognitive strategy-based instruction. Learners who understand the processes of listening and believe they have the ability to reach their goals will be more ready to handle challenging listening tasks and set demanding goals for their listening development [4] [15].

\section{B. Metacognition in listening}

According to Flavel [1], metacognition refers to individuals' knowledge about their own cognition or anything related to them. Regarding awareness, Flavel [1] differentiate metacognitive experience and metacognitive knowledge. Metacognitive experience is what learners feel about their cognition while metacognitive knowledge is related to beliefs and knowledge about learning. Flavel [1] distinguished three dimensions of this knowledge: person, task, and strategy. Person knowledge refers to knowledge about selves as learners, and the perception of one's own abilities and factors contributing to success or failure in learning; task knowledge is knowledge of the procedures in accomplishing tasks; and strategy knowledge is knowledge about which strategies are useful for achieving learning goals.

Learners' introspective awareness and control of cognitive processes is the essential component of metacognitive instruction. Thus, they should be aware of mental processes when performing a learning task and self-regulate the processes in order to achieve the goal of the task [4]. It is proven by Vandergrift [20] who found skilled listeners "able to systematically orchestrate a cycle of cognitive and metacognitive strategies to arrive at a coherent mental representation of the text in memory". It even applies to young learners. Vandergrift [20] showed that when Grade 4 to 6 students completed reflection exercises, they became sensitized to listening processes and nurtured their metacognitive knowledge. Mareschal [11] found that there was an increase in metacognitive awareness, strategy use, confidence and interest in listening among students of different proficiency levels. In this research, low proficiency students were the ones who benefited the most.

\section{Previous studies on metacognitive awareness in listening in EFL context.}

Goh and Taib [3] found that a group of young ESL learners who had metacognitive instruction in listening lessons mentioned that they had better knowledge of the nature and the demands of listening tasks, higher confidence in coping with tasks, and better strategic knowledge for handling comprehension difficulties. Similarly, Zeng [22] who conducted a randomized intervention study in which thirty students in the experimental group received training in the use of selected listening strategies and process-based listening activities showed a statistically significant improvement in their listening examination scores compared with the control group, which received the traditional, teacher-centred mode of listening instruction. Vandergrift et.al [21] investigated the effects of using a lesson sequence that incorporated a "metacognitive cycle" on the listening performance of a group of French learners found that the experimental got a higher degree of metacognitive awareness and achieved significantly better results in their listening test.

In Indonesian context, studies on metacognitive awareness are still very few. Most researches that have been conducted are mostly on correlation between metacognitive strategy and listening comprehension, not on the students' awareness itself. For example, Nurhidayah and Ma'mun [14] did a study on the use of metacognitive instruction to improve the students' ability on listening section of the TOEFL test. Their focus is on the contribution of metacognitive instruction on the improvement of the listening skill. They did not discuss the students' metacognitive awareness.

\section{RESEARCH QUESTION}

Sariswara There are two research questions underlying this study. They are:

1. To what extent is the students' metacognitive awareness in listening to English as a foreign language?

2. What are the relationships between the students' perception of only being tested or taught about listening strategy use and various aspects of metacognitive awareness?

\section{METHOD}

This study utilized a questionnaire to obtain data from the respondents. The questionnaire was distributed to 80 sophomore students who play role as the participants of this study. Sophomores were chosen because they are considered experienced in listening classes. They have taken 3 different levels of listening classes. Their answers in the questionnaire contribute to reveal their metacognitive awareness and the instructional process of listening classes.

The questionnaire used was adapted from Vandergrift and Goh's MALQ (Metacognitive Awareness Listening Questionnaire). Some questions, especially whether they feel like only being tested or trained listening strategies, were added to get responses related to the teaching-learning process of listening subjects taken by the participants. The data were analyzed using descriptive statistics and bivariate Pearson correlation.

\section{RESULTS AND DISCUSSION}

\section{A. The extent of students' listening metacognitive awareness}

Results indicate that in general the students had fairly high metacognitive knowledge and strategies in EFL listening with the overall mean score of 4.34 on a 6-point scale. As indicated in Table 1, the mean of students' awareness of planning and evaluation was 4.46 , which is fairly high. The means of the 
items of planning and evaluation subscale ranged from 4.14 to 4.73. This suggests that the students were quite aware of planning processes before and during listening to an English text, as well as evaluating their comprehension after listening activities. Further, the students demonstrated a slightly higher level of awareness in directed attention $(\mathrm{M}=4.63)$, and the average scores of this aspect's four items ranged from 4.42 to 4.86. In this regard, the students reported that they tried hard to focus or direct their attention to given tasks when losing concentration or having trouble in comprehending a text. They also didn't easily give up when faced with difficult listening texts. Likewise, the students had quite high awareness of problem solving strategies $(M=4.74)$, with the mean range of the subscale items from 4.19 to 5 . They made use of their knowledge, including their vocabulary and general idea of the text, to help them understand a text and guess word meanings. On average, the students also reported moderate awareness of person knowledge $(\mathrm{M}=4.23)$. They considered listening an English text a challenge $(\mathrm{M}=4.93)$ and more difficult compared to other skills $(\mathrm{M}=3.7)$, but they were mostly not nervous dealing with it $(M=4.07)$. Comparatively, the students had a lower awareness of mental translation strategies $(\mathrm{M}=3.65)$. While listening, they reportedly translated in head $(M=4.19)$ and key words $(M=4.25)$, but they rarely translated word by word $(\mathrm{M}=2.52)$.

Compared to the findings of Goh and Hu's [23] study on Chinese students taking a six-month English program in Singapore, the participants in this study had higher awareness in strategies of planning and evaluation, directed attention, mental translation and person knowledge, but they had slightly lower awareness of problem solving strategies. This might be because the participants were students majoring English education and many of them might have been trained in listening strategies. With such a level of metacognitive awareness, the students are likely to have a control of cognitive processes self-regulate the process during listening task completion [4] [20]. The following table shows the mean scores of metacognitive awareness in fie aspects of awareness i.e. planning evaluation, directed attention, person knowledge, mental translation, and problem solving.

TABLE 1. MEAN SCORES OF METACOGNITIVE AWARENESS ITEMS

\begin{tabular}{|r|r|r|r|}
\hline No & \multicolumn{1}{|c|}{ Items } & \multicolumn{1}{|c|}{$\boldsymbol{M}$} & SD \\
\hline Planning-evaluation & 4.73 & 1.01 \\
\hline 1 & Planning in head how to listen & 4.34 & 4.5 \\
\hline 2 & $\begin{array}{l}\text { Prior listening, thinking of similar texts that } \\
\text { may have been listened to }\end{array}$ & 4.59 & 1.14 \\
\hline 3 & $\begin{array}{l}\text { After listening, thinking back to the way of } \\
\text { listening and what to do next }\end{array}$ & 4.14 & 1.13 \\
\hline 4 & $\begin{array}{l}\text { As listening, asking oneself if satisfied with } \\
\text { one's own comprehension. }\end{array}$ & 4.53 & 1.14 \\
\hline 5 & Having a goal in mind as listening. & 4.46 & 0.78 \\
\hline & \multicolumn{2}{|c|}{ Average score } \\
\hline Directed attention & $\begin{array}{l}\text { Focusing on the text when having trouble in } \\
\text { understanding }\end{array}$ & 4.86 & 1.11 \\
\hline 7 & $\begin{array}{l}\text { Recovering concentration right away when } \\
\text { distracted }\end{array}$ & 4.63 & 1.01 \\
\hline 8 & $\begin{array}{l}\text { Trying to get back on track when losing } \\
\text { concentration }\end{array}$ & 1.15 \\
\hline
\end{tabular}

\begin{tabular}{|c|c|c|c|}
\hline 9 & $\begin{array}{l}\text { Not giving up listening when having difficulty } \\
\text { understanding }\end{array}$ & 4.63 & 1.34 \\
\hline & Average score & 4.63 & 0.68 \\
\hline \multicolumn{4}{|c|}{ Person knowledge } \\
\hline 10 & Listening is harder than other skills & 3.7 & 1.43 \\
\hline 11 & Listening is a challenge & 4.93 & 1.34 \\
\hline \multirow[t]{2}{*}{12} & Not nervous when listening to English & 4.07 & 1.13 \\
\hline & Average score & 4.23 & 0.79 \\
\hline \multicolumn{4}{|c|}{ Mental translation } \\
\hline 13 & Translating in head while listening & 4.19 & 1.01 \\
\hline 14 & Translating key words as listening & 4.25 & 1.22 \\
\hline \multirow[t]{2}{*}{15} & Translating word by word as listening & 2.52 & 1.3 \\
\hline & Average score & 3.65 & 1.01 \\
\hline \multicolumn{4}{|c|}{ Problem solving } \\
\hline 16 & $\begin{array}{l}\text { Using known words to guess the meaning of the } \\
\text { unknown words }\end{array}$ & 4.98 & 1.01 \\
\hline 17 & $\begin{array}{l}\text { Comparing what is understood with knowledge } \\
\text { about the topic }\end{array}$ & 5 & 0.94 \\
\hline 18 & $\begin{array}{l}\text { Using experience and knowledge to help } \\
\text { understanding }\end{array}$ & 5.04 & 1.01 \\
\hline 19 & $\begin{array}{l}\text { Adjusting interpretation when it is not } \\
\text { correct }\end{array}$ & 4.63 & 0.85 \\
\hline 20 & $\begin{array}{l}\text { Using the general idea of the text to guess the } \\
\text { meaning of unknown words }\end{array}$ & 4.61 & 1.35 \\
\hline \multirow[t]{2}{*}{21} & $\begin{array}{l}\text { When guessing a word, thinking back to see if } \\
\text { the guess makes sense. }\end{array}$ & 4.19 & 1.13 \\
\hline & Average score & 4.74 & 0.75 \\
\hline \multicolumn{2}{|c|}{ Overall average score } & 4.34 & 0.8 \\
\hline
\end{tabular}

\section{B. The relationship between the perception of only being tested and that of being trained listening strategies and metacognitive awareness}

Results of the Pearson correlation analyses showed no significant relationships between the perception of only being tested and not trained in listening strategies by their teachers and the five aspects of metacognitive awareness (see Table 2). On the contrary, the perception of being trained listening strategies was significantly related to planning and evaluation, directed attention, and problem solving, but not to mental translation and person knowledge. The findings suggested that students who perceived themselves being trained in listening strategies in the listening class tended to have higher awareness of planning and evaluating their learning process and results than those who didn't. Those students also were likely to be better at focusing or reorienting attention and not easily give up instantly when faced with difficult listening tasks, and at using strategies in solving problems. 
TABLE 2. CORRELATIONS BETWEEN METACOGNITIVE AWARENESS AND THE PERCEPTION OF BEING TRAINED STRATEGIES AND TESTED

\begin{tabular}{|l|r|r|}
\hline $\begin{array}{c}\text { Aspects of metacognitive } \\
\text { awareness }\end{array}$ & $\begin{array}{c}\text { Perception of } \\
\text { only being tested }\end{array}$ & $\begin{array}{c}\text { Perception of being } \\
\text { trained in strategies }\end{array}$ \\
\hline planning and evaluation & -0.054 & $.432^{*}$ \\
\hline directed attention & 0.088 & $.567^{*}$ \\
\hline person knowledge & 0.086 & $.305^{*}$ \\
\hline mental translation & 0.143 & 0.175 \\
\hline problem solving & -0.121 & $.375^{*}$ \\
\hline
\end{tabular}

Note: $* \mathrm{p}<.05$

This finding, although it should be read with great caution, agrees with that of past studies [3] [9] [10] [22] that students who are trained in using listening strategies are likely to have greater strategic knowledge. The students in this study who perceived that their teacher trained them in using listening strategies might have been taught strategies implicitly. Through strategy training whether explicit and implicit, students develop their awareness of how to self-regulate their cognitive and affective processes and exercise strategic knowledge at their disposal to cope with listening tasks.

\section{CONCLUSION}

This study reveals that metacognitive awareness is the foundation of students' listening strategy development. Metacognitive awareness helps students to manage themselves to be self-regulated in practices EFL listening skill because they are aware of the planning process before and during listening as well as knowing how to manage their focus and concentration in facing any kinds of listening materials. Another thing revealed is the importance of making sure that the students in listening class are taught listening strategies explicitly. Teaching them the strategies explicitly is more beneficial for the students. The teaching of listening strategies helps students to have greater strategic knowledge, to be able to plan and assess themselves in listening practices, and to be less anxious in dealing with challenges encountered during listening. Some further studies might be conducted corresponding the finding of this study. For example, studies on correlation between awareness and students' listening ability. Another example is deeper studies on how explicit and implicit teaching of listening strategies affect learning outcome and students' anxiety. Beside the two previous examples, studies on teachers' perception on the use of explicit and implicit listening strategies and their impacts to listening ability can also be conducted.

\section{REFERENCES}

[1] J. H. Flavell, P. H. Miller, and S. A. Miller, Cognitive Development (Third Edition). Englewood Cliffs, New Jersey: Prentice Hall, 1993.

[2] C. Goh, "A cognitive perspective on language learners' listening comprehension problem," System, vol. 28, pp. 55-75, 2000.

[3] C. Goh \& Y. Taib, "Metacognitive instruction in listening for young learners," ELT Journal, vol. 60/3, pp. 222 - 232, 2006.

[4] C. Goh, Listening as process: Learning activities for self-appraisal and self- regulation. in English language teaching materials: Theory and practice, Cambridge University Press, pp. 179-206, 2010.
[5] M. Helgesen, Listening in Practical Language Teaching, edited by David Nunan, 2003.

[6] E. Hinkel, "Current perspectives on teaching the four skills," TESOL Quarterly, vol. 40, pp. 109-131, 2006.

[7] W. Li, and W. A. Renandya, "Effective Approaches to Teaching Listening: Chinese EFL Teachers' Perspectives," In The Journal of Asia Tefl, vol. 9, no. 4, pp. 79-111, 2012.

[8] S. Lawes, and D. Santos, "Teaching learning strategies: what do teachers learn?," Language Learning Journal, vol. 35, pp. 221-237, 2007.

[9] E. Macaro, "Strategies for language learning and for language use: Revising the theoretical framework," The Modern Language Journal, vol. 90, pp. 320-337, 2006.

[10] S. Graham, E. Macaro, and R.Vanderplank, A review of listening strategies: focus on sources of knowledge and on success. In: A.D. Cohen \& E. Macaro (Eds.), Language Learner Strategies: 30 Years of Research and Practice (pp. 165-185). Oxford: Oxford University Press, 2007.

[11] C. Mareschal, Student perceptions of a self-regulatory approach to second language listening comprehension development, Unpublished PhD thesis, University of Ottawa, Canada, 2007.

[12] D. Mendelsohn, "The lecture buddy project: An experiment in EAP listening comprehension," TESL Canada Journal, vol. 20, no. 1, pp. 64-73, 2002.

[13] P. Nathan, Collaboration and Metacognitive Awareness in Second Language Listening Comprehension. Unpublished MA thesis, National Institute of Education, Nanyang Technological University, Singapore, 2008.

[14] Nurhidayah, and Ma'mun, "Improving Listening Skill of Students Using Metacognitive Instruction,"Ijet," State Islamic University of Sunan Ampel Surabaya, vol. 5, no 2, 2016.

[15] N. Osada, "What strategy do less proficient learners employ in listening comprehension? A reappraisal of bottom-up and top-down processing," Pan-Pacific Association of Applied Linguistics, vol. 5, pp. 73-90, 2001.

[16] M. Rost, Teaching and researching listening. London, UK: Longman, 2011.

[17] N. Segalowitz, Automaticity and second language. In C. Doughty \& M. Long (Eds.), The handbook of second language acquisition (pp. 382-408). MA: Blackwell Publishing, 2003.

[18] M. H. Tan, "Developing metacognitive awareness of listening comprehension using information technology,"MMM800 Critical Inquiry paper, National Institute of Education, Singapore, 2007.

[19] B. Tyagi, "Listening: An Important Skill and Its Various Aspects," The Criterion An International Journal in English. vol. 12, pp. 1-8, 2013.

[20] L. Vandergrift, "Learning to listen or listening to learn," Annual Review of Applied Linguistics, vol. 24, pp. 3-25, 2004.

[21] L. Vandergrift, C. C. M. Goh, C. J. Mareschal, and M. H. Tafaghodtari, "The Metacognitive Awareness Listening Questionnaire (MALQ): Development and validation," Language Learning, vol. 56, pp. 431-62, 2006.

[22] Y. Zeng, "Metacognitive instruction in listening: A study of Chinese non-English major undergraduates," Unpublished MA thesis. National Institute of Education, Nanyang Technological University, Singapore, 2007.

[23] C. Goh, and G. Hu, "Exploring the relationship between metacognitive awareness and listening performance with questionnaire data," Language Awareness, vol. 23(3), pp. 255-274, 2013. http://dx.doi.org/10.1080/09658416.2013.769558 